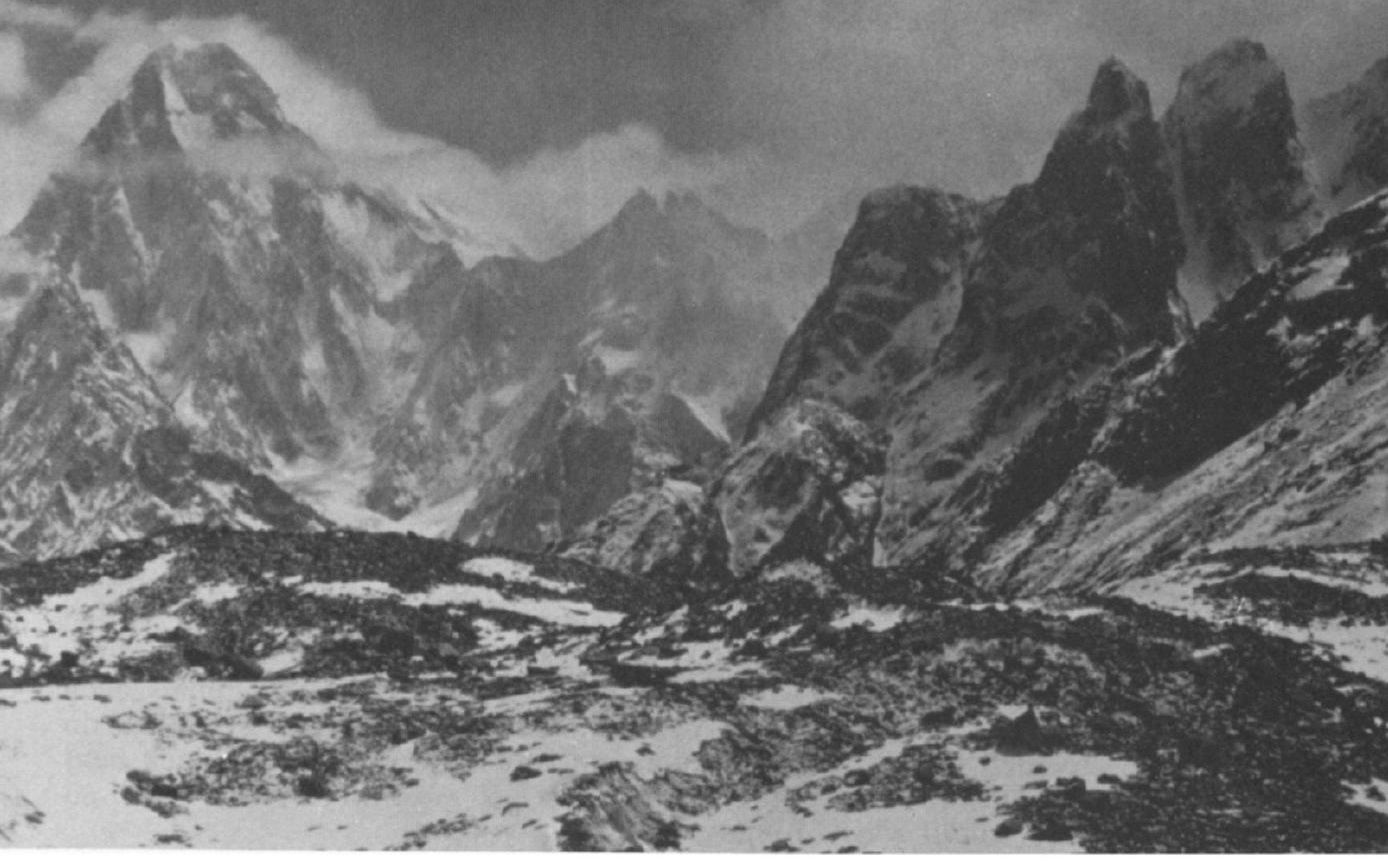

George B. Schaller

\title{
Mountain Mammals in Pakistan
}

George B. Schaller

The author spent eleven months between 1970 and 1975 studying the wildlife of the high mountains in northern Pakistan, especially the large mammals that are endangered in Pakistan. He describes the status of nine, of which the brown bear is on the verge of extinction there (although commonly seen in the form of performing bears in city streets), while the Kashmir markhor, snow leopard and Marco Polo sheep are in serious danger. Despite the protection laws and new reserves, including a new national park, the rule is still too often 'if it moves shoot it, if it doesn't chop it down'.

The Hindu Kush, Himalaya, and Karakoram ranges meet in northern Pakistan to form a tremendous mountain region some $100,000 \mathrm{sq} \mathrm{km}$ in extent. The summer monsoon reaches the southern hills, making them quite lush, with forests of oak, fir, pine and other trees up to the timberline at about $4000 \mathrm{~m}$. Further north, beyond the towns of Chitral and Gilgit, the ranges are bleak and cold. With precipitation of less than $50 \mathrm{~cm}$ per year, much of it as snow, the terrain is desolate glaciers and rock and wind-flayed slopes sparsely dotted with Artemisia, Ephedra, and other low shrubs. Alpine meadows and groves of birch and willow hug the stream edges or grow on sites nurtured by meltwater from the perpetual snows.

But these remote and inhospitable mountains support a large human population. In the fertile southern portions most forests have been cut and the 
slopes converted into terraced fields. In the arid areas, where irrigation is necessary to grow crops, villages and fields occupy almost every level piece of ground and every alluvial fan at the mouths of streams up to an altitude of $3400 \mathrm{~m}$. For instance, the Baltistan area around Skardu, $25,000 \mathrm{sq} \mathrm{km}$ in size, has a population of 300,000 , and 2 per cent of the land is cultivated. Yet such figures do little to convey man's pervasiveness. Sheep, goats, yaks and other livestock forage up to $4700 \mathrm{~m}$, close to the vegetation limit. Woodcutters fell the gnarled junipers on the crags for fuel, and when these are gone rip Artemisia and other shrubs from the fragile slopes.

In spite of this enduring presence of man, the mountains once supported much wildlife, as early hunting accounts by Burrard (1925), Stockley (1936) and others testify. Wars with India and strained relations with Afghanistan have made northern Pakistan politically sensitive; the country is intermittently closed to foreigners with the result that little information about the status of the fauna has been available during the past forty years. Spurred on by Mountfort ${ }^{4}$ and Roberts, ${ }^{5}$ whose notes suggested that wildlife had greatly declined, I spent eleven months in these mountains between 1970 and 1975 to make surveys and study selected animal populations, particularly the wild goats and sheep threatened with extinction in Pakistan. Some mammals, such as Eurasian otter Lutra lutra and lynx Felis lynx, were so rare that I could do little more than record their presence, and others, among them black bear Selenarctos thibetanus and muskdeer Moschus moschiferus, are localised forest species about which I learned little.

Markhor. With their long, spiralling horns and flowing neck ruff, markhor Capra falconeri are the most distinctive of the wild goats. Two subspecies, the Kashmir and Astor markhors, are said to occur in northern Pakistan. While I continue to use these common names, the two forms are best placed into one subspecies, C.f. megaceros. ${ }^{6}$ Their habitat requirements include cliffs into which they can escape in times of danger, and some suitable terrain below $2200 \mathrm{~m}$ where temperatures remain moderate in winter. Although in summer they may go as high as $4000 \mathrm{~m}$, their low tolerance of cold has restricted them to low-lying valleys such as the Indus. Otherwise they are ecologically quite tolerant, existing both on treeless slopes and among evergreen oak whose leathery leaves provide one of their main winter foods.

The Kashmir markhor survives in several small populations in eastern Afghanistan, in the Chitral, Dir, and Swat districts of Pakistan, and then again far to the south-east, in the Pir Panjal Range of India. Chitral was once famous for this markhor, and many small valleys such as the Drosh Gol contained 500 and more animals. Today most of these populations have been exterminated or reduced to tiny remnants. Exceptions are the Chitral Gol and Tushi, both private reserves belonging to the royal family of Chitral, each of which contains about 125 markhor. Probably fewer than 1500 Kashmir markhor remain in the western part of their range; of these perhaps a third occur in Chitral.

Astor markhor frequent the scattered cliffs bordering the Indus and its tributaries. The new roads along all the major valleys have opened up once remote terrain to motorised hunters who can now shoot markhor with ease when the animals descend to their winter ranges, and their decline has been drastic, whole populations having disappeared along the upper Gilgit River. 


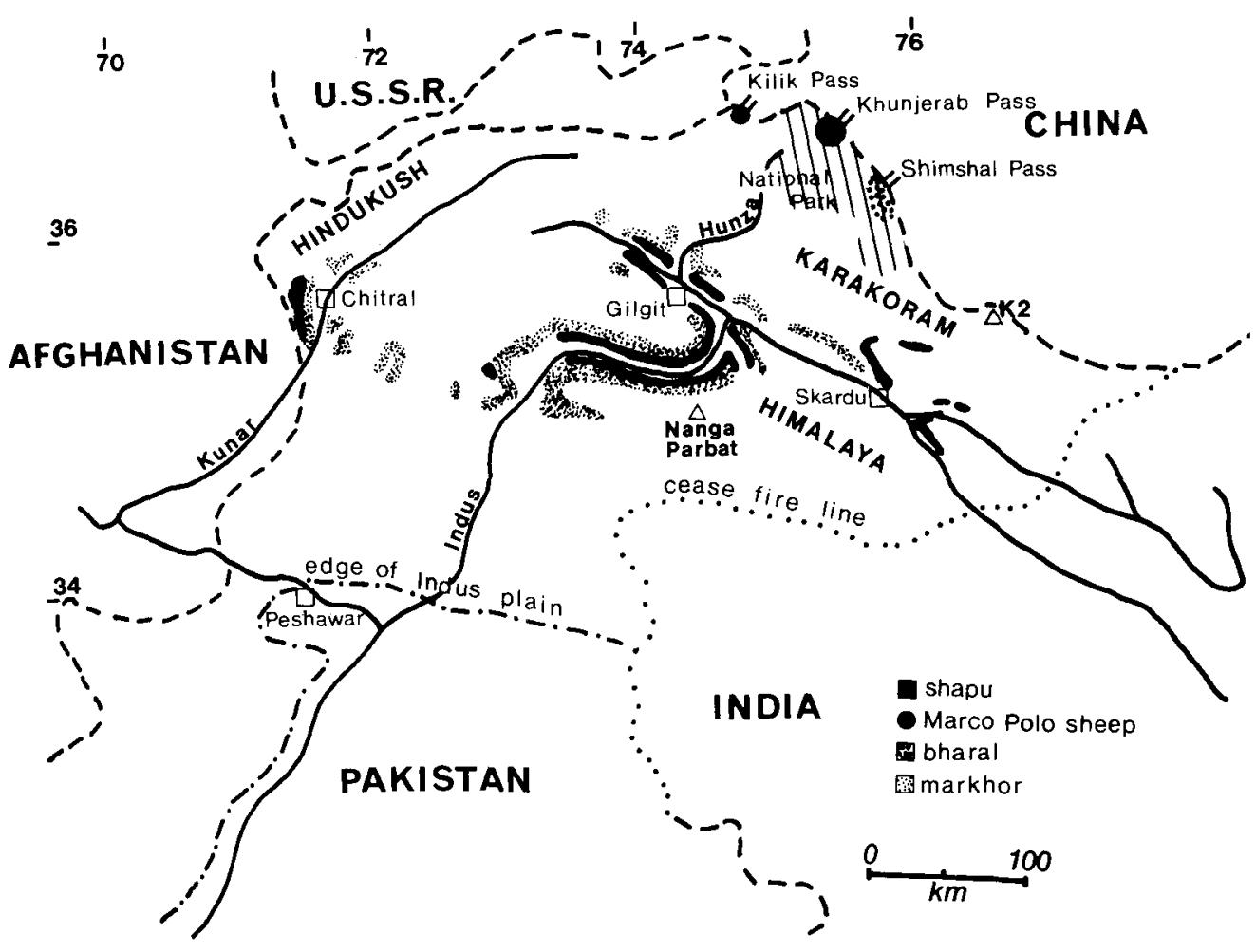

Several years ago Roberts ${ }^{5}$ estimated 'not less than 500 to 600 ' markhor in the Kargah Valley; today only about 50 survive. I cannot estimate the number of Astor markhor but would guess that they are still at least twice as abundant as the Kashmir markhor.

Asiatic Ibex. The ibex Capra ibex sibirica is the most widespread and abundant wild ungulate in the mountains. Essentially confined to the alpine zone between 3500 and $5000 \mathrm{~m}$, the animals have been able by virtue of their habitat, to elude the casual shooter. Yet densities are generally low, partly due to the fragmented habitat, the tiny oases of green hidden in the haggard waste of rock and snow, and partly to persistent persecution by meat hunters. In the valleys around Kilik Pass in Hunza, where a local military unit had shot at least 60 in the winter of 1972-73, I tallied only 59 ibex, about 0.4 animals per sq $\mathrm{km}$. Around the Dorah Pass area of Chitral, once famous for ibex, a week-long search revealed only 10 animals in $50 \mathrm{sq} \mathrm{km}$. However, in the privately protected Besti region of Chitral, 72 ibex were found in $40 \mathrm{sq}$ $\mathrm{km}$. Not included in such tallies are the vast expanses of sterile uplands which are almost devoid of wildlife. For example, along $30 \mathrm{~km}$ of northfacing slopes along and near the Baltoro glacier 49 ibex were spotted. At that season perhaps only 100 animals existed there in at least $1400 \mathrm{sq} \mathrm{km}$ of glaciers and bare cliffs. By way of contrast, in the eastern Pamir, Heptner et $\mathrm{al}^{3}$ reported 600 ibex in $100 \mathrm{sq} \mathrm{km}$.

Shapu. Like all urials, the shapu or Ladak urial Ovis orientalis vignei prefers rolling but not precipitous terrain at low altitudes. This sheep penetrated the 
mountains by following major rivers, as the markhor did. In 1841 Blyth wrote, 'Vast numbers of this species are driven down by the snow in winter to the branches of the Indus, near Astor... Unfortunately man and his livestock have usurped most shapu habitat, and downstream of Skardu the species is now virtually extinct. The sighting of a shapu in Chitral is today a noteworthy event, whereas even 40 years ago they are said to have numbered thousands. Small populations persist in the Shigar Valley north of Skardu, as well as in the Braldo valley, where I saw 38 sheep at $3400 \mathrm{~m}$ near the Baltoro glacier; along the Indus and Shyok, too, are some survivors. On the whole, however, the status of this subspecies is critical. Fewer than 1000 animals in small vulnerable populations are left in the country.

Marco Polo Sheep. Ovis ammon polii is one of the most coveted trophies because of its huge horns. Its range in Pakistan consists of only some $55 \mathrm{sq}$ $\mathrm{km}$ of rolling terrain above $4500 \mathrm{~m}$ around the Kilik and Khunjerab passes in northern Hunza. This limited habitat, coupled with extensive hunting, has made it one of the rarest animals in the country. At one time polii flocked into Pakistan from the Tagdumbash Pamir in Sinkiang Province because the Khirgiz tribesmen there hunted the animals with dogs, whereas the ruler of Hunza protected them. As recently as November 1959, the American hunter Elgin Gates saw a herd of 65 rams at Khunjerab Pass, and is said to have shot at least five, an action which presaged the fate of the species there. The construction in the late 1960s of the Karakoram Highway, linking Pakistan with China via the Khunjerab Pass, almost doomed the sheep. In 1968 one military officer shot fifty for meat, and the possession of Marco Polo sheep trophies became a status symbol in Pakistani homes, just as a tigerskin rug once was in India. Fortunately China has protected the species for over twenty years and provided the survivors from Pakistan with a safe haven. At present the Marco Polo sheep is only a sporadic visitor to the Kilik and Khunjerab passes; there was not a single animal there when I visited the areas in November 1974.

Bharal and Kiang. The Shimshal Pass in north-eastern Hunza, which I did not visit, is the home of these two species which are found nowhere else in Pakistan. For the bharal Pseudois nayaur, a goat, this represents the most westerly extension of its range, but I do not know how abundant it is; judging by Shipton's account, ${ }^{7}$ the herds are readily seen. Villagers told me that the kiang or Tibetan wild ass Equus kiang is an occasional visitor to the upper Shimshal Valley.

Snow leopard. Panthera uncia is exceedingly rare throughout the high ranges. With wildlife so scarce, the cats must either travel far in search of prey or subsist on domestic stock, the latter habit guaranteeing them a short life expectancy. I made intensive surveys only in Chitral, although I saw tracks at Kilik Pass and along the Baltoro glacier. In December 1970, I saw two snow leopards in the Chitral Gol reserve and the tracks of a third. Their food at that time consisted mainly of domestic goats and sheep (found in 50 per cent of the droppings), markhor (in 31 per cent) and Rheum forbs (in 13 per cent). At least six snow leopards were shot in the vicinity of the reserve in the 1971-72 winter. The following winter two visited the Chitral Gol briefly, and at least one was shot nearby that year. In the 1973-74 and 
Table 1 Ratios of adult females to young (0-12 months) and yearlings (12-24 months)

\begin{tabular}{lllcc} 
Species & \multicolumn{1}{c}{ Locality } & Date & $\begin{array}{c}\text { Yearlings per } \\
\text { 100 ad.females }\end{array}$ 100 ad.females \\
Asiatic ibex & Besti, Chitral & Feb. '74 & 64 & 64 \\
& Kilik, Hunza & Nov.'74 & 50 & 67 \\
Kashmir markhor & Baltoro, Baltistan & May. '75 & 35 & 80 \\
Chitral Gol, Chitral & Jan.'73 & 44 & 124 \\
Shapu & Tushi, Chitral & Jan. '73 & 57 & 107 \\
& Baltoro, Baltistan & May'75 & 50 & 54
\end{tabular}

* Since most births occurred in June, all young were at least 4 months old.

1974-75 winters no snow leopards came to the reserve. In February 1974, I censused snow leopards in about $300 \mathrm{sq} \mathrm{km}$ of Chitral and found evidence of four or possibly five. Within four years the status of the snow leopard there had changed from tenuous security to seriously threatened, and it is not just coincidence that the decline occurred during a political and legal interregnum, when the semi-autonomous state of Chitral was absorbed into the North-West Frontier Province. One estimate places the number of snow leopards in Pakistan at about $100 .{ }^{1}$ I cannot provide a precise figure but feel sure that fewer than 250 survive in the country.

Brown bear. Ursus arctos is readily seen in Pakistan - as dancing bears on the streets of Lahore and Peshawar. Gypsies and other itinerant entertainers provide a ready market for cubs captured by herdsmen in the mountains after shooting the mother.

The brown bear's status is even more critical than that of the snow leopard. It is virtually extinct in the 11,250 -sq-km Chitral district, the only spoor I ever saw there was near the Karambar Pass and it is equally scarce in most other ranges. At Kunjerab Pass a bear had excavated a burrow in pursuit of marmots, and the droppings of one or more bears near the Baltoro glacier showed that the animals lived on grass (in 69 per cent of the droppings), roots (in 34 per cent), and ibex killed by avalanches (in 16 per cent). I mention these trivial observations to show that the finding of occasional bear spoor is a notable event. The last stronghold of the species in Pakistan may be on the Deosai Plains southwest of Skardu, but no survey has been made there yet.

Wolf. Canis lupus, though uncommon, is periodically obtrusive, for wolves may sweep close to a village, kill a domestic goat or two, bolt some meat, and vanish as suddenly as they arrived. I encountered them only twice. On one occasion in the Chitral Gol, two wolves chased nine markhor unsuccessfully, and on another two wolves followed an ibex trail at $4800 \mathrm{~m}$ near Kilik Pass. An analysis of 63 sets of droppings in the northern area revealed their opportunistic diet: domestic stock (in 38 per cent), ibex (37 per cent), marmot (17 per cent), and shapu, Marco Polo sheep, hare, and grass (2 per cent each).

\section{Conservation}

Although many mountain slopes have been denuded, their forests felled and the ground cover devastated by livestock, such degraded habitat could nevertheless support more wildlife than it does now. Several small surviving populations of wild sheep and goats are reproducing adequately, as Table 1 shows, the markhor even giving birth to twins quite commonly. With natural 
predators scarce, these populations could be expected to increase - if poaching were fully controlled.

Legislation for the proper protection of wildlife exists now in most areas. In 1973 the Deputy Commissioner of Chitral prohibited the shooting of large mammals, and in the same year hunting was banned in the Gilgit Agency by the Central Government. This had a dramatic effect. Within a year everyone knew of (though did not necessarily honour) the new restrictions. In the mountains the time-honored slogan, 'If it moves, shoot it; if it doesn't, chop it down', is still practised with some vigour. But in the government a new awareness of wildlife conservation now permeates all levels, partly stimulated by the realisation that a herd of Marco Polo sheep or a snow leopard on a kill make unique tourist attractions. Sanctuaries have been officially designated, among them the Chitral Gol, and national park status has been proposed for Nanga Parbat and for K2, at $8611 \mathrm{~m}$ the second highest peak in the world. A most significant conservation step was the establishment on April 29th, 1975 of the Khunjerab National Park in northern Hunza, by order of Prime Minister Zulfikar Ali Bhutto. Covering $2200 \mathrm{sq}$ $\mathrm{km}$ and with no permanent human habitation, this park protects both Marco Polo sheep and bharal. These and other steps augur well for at least some wildlife and its habitat, though several species, such as the shapu, are still not adequately protected in reserves.

The mountains will retain their beauty without the animals, but when the last brown bear has disappeared from the alpine meadows and the last snow leopard from the crags, a spark of life will have gone too, turning the peaks into stones of silence.

\section{Acknowledgments}

I am grateful to the New York Zoological Society and National Geographic Society for funding the project, to World Wildlife Fund Pakistan for sponsoring it locally, and to the many persons, especially to S. B. Ali, Z. B. Mirza, S. A. Khan, P. A. Khan, G. M. Beg, and Shahzadas Asad-ur-Rehman and Burhan-ud-Din, who helped in various ways. Nicole Duplaix-Hall kindly prepared the map.

\section{References}

1. ANON, 1972. The snow leopard in Pakistan. Animals, 14(6): 256-259.

2. BURRARD, G. 1925. Big game hunting in the Himalayas and Tibet. London.

3. HEPTNER, V., NASIMOVIC, A. and BANNIKOV, A. 1966. Die Säugetiere der Sowjetunion. Jena.

4. MOUNTFORT, G. 1969. The vanishing jungle. Collins, London.

5. ROBERTS, T. 1969. A note on Capra falconeri (Wagner, 1839). Z. f. Säugetierkunde. 34(4): $238-249$.

6. SCHALLER, G. and KHAN, A. 1975. Distribution and status of markhor (Capra falconeri). Biol. Cons. in press.

7. SHIPTON, E. 1938. Blank on the map. London.

8. STOCKLEY, C. 1936. Stalking in the Himalayas and Northern India. London.

Dr Schaller is the Co-ordinator of the New York Zoological Society's Center for Field Biology and Conservation.

\section{Bahrain Mammals}

In a paper on the mammals of Bahrain, in the Bombay Natural History Society Journal, 72, 2, Michael Gallagher and David L. Harrison list 13 terrestrial species so far discovered, of which eight have not been previously reported. The local hedgehog Paraechinus aethiopicus may yet be shown to be a separate race. The hare and the gazelle are protected, although the former gets shot. 